\title{
Fundamentals of an applied ecosystem research project in the Wadden Sea of Schleswig-Holstein*
}

\author{
Christoph Leuschner ${ }^{1} \&$ Bernd Scherer ${ }^{2}$ \\ ${ }^{1}$ Systematisch-Geobotanisches Institut der Universität; Untere Karspüle 2, \\ D-3400 Göttingen, Federal Republic of Germany \\ ${ }^{2}$ Landesamt für den Nationalpark Schleswig-Holsteinisches Wattenmeer; Am Hafen 40a, \\ D-2253 Tönning, Federal Republic of Germany
}

\begin{abstract}
The aims, content, and organisatory structure of a proposed interdisciplinary ecosystem research project in the Wadden Sea of Schleswig-Holstein (W. Germany) are briefly presented. The project will include research on both fundamental as well as applied aspects of the Wadden Sea ecosystems and their interaction with local human activities. In contrast to most of the other completed or currently running ecosystem research projects on tidal coasts, a considerable part of the scientific work will also deal with aspects of ecosystem management and protection of the various marine and semiterrestrial habitats of the Wadden Sea. Considerable attention is paid to theoretical and methodological aspects of research on ecosystems and landscape units. In particular, the adoption of a hierarchical view of complex biological and environmental systems is recommended.
\end{abstract}

\section{INTRODUCTION}

Coastal regions have always been those parts of the seas that have suffered most from extensive impact by man. Right up to the more recent past this meant no serious threat to these usually highly productive and also vulnerable ecosystems. In our times, however, the coastal regions of industrial nations have to bear an ever increasing burden of nutrient and pollutant input via rivers, the atmosphere, coastal discharges, and direct release at sea. At the same time these regions are used intensively for food production and recreation.

The two-fold human impact through matter input and resource use also poses a threat to the coastal ecosystems of the Wadden Sea of the German North Sea coast. This has recently led to increasing concern about the environmental quality of these ecosystems. On October 1st 1985, the Wadden Sea of the state of Schleswig-Holstein (Federal Republic of Germany) was declared a national park. The ensuing contacts between the Umweltbundesamt (Federal Environmental Office at Berlin) and the Nationalparkamt (National Park Office at Tönning) resulted in the first author's study on the fundamentals, aims, content, and organisatory structure of an ecosystem research project within the Wadden Sea of Schleswig-Holstein. Among the aims of this project the applied aspects are of high priority.

- Presented at the VI International Wadden Sea Symposium (Biologische Anstalt Helgoland, Wattenmeerstation Sylt, D-2282 List, FRG, 1-4 November 1988) 
Based on the results of the project's conceptual study (Leuschner, 1988) research work will start in 1989 for an initial period of 5 years. Funding institutions will probably be the Federal Ministry of the Environment, Nature Conservation, and Nuclear Safety, the Federal Ministry of Research and Technology as well as the Ministry of Nature and Environment of the state of Schleswig-Holstein. Participating scientific institutions will be the universities of Kiel and Hamburg, Biologische Anstalt Helgoland, GKSS-Forschungszentrum at Geesthacht as well as several scientists from other German and Danish institutions.

A comparable research project on the Wadden Sea to be carried out within the state of Niedersachsen (Federal Republic of Germany) is currently being planned (ARSU, 1988).

\section{ECOSYSTEMS AND LANDSCAPE UNITS AS OBJECTS OF RESEARCH}

In order to meet the growing demand for ecological knowledge on the part of administration and the environmental policy makers, a new type of ecosystem research project has recently been evolved in the Federal Republic of Germany (e.g. Ökosystemforschung Berchtesgaden). Three main properties characterize these scientific efforts:

(a) Objects of research are not solely selected examples of ecosystem stands with limited areal extension but complete landscape units which comprise a mosaic of different ecosystem types. Thus research includes an approach to collect environmental data in its regional variability.

(b) To cover man's influence on ecosystems the research program includes contrib u tions from the social and economical sciences.

(c) In order to improve interdisciplinary and synthetical research within the project, the establishment of an effective project management is emphasized.

The Wadden Sea of the southern coast of the North Sea has faced the pressure of human settlement and influence for a long time. Therefore, man is an integral part of its ecosystems. Thus, the adoption of the above mentioned aspects in the context of ecosystem research will clearly be useful in order to reach a comprehensive scientific understanding of the Wadden Sea's natural and man-made systems.

Three main goals are basic to the set-up of the research concept:

(1) To gain a fundamental understanding of the functions of natural and man-made systems within the Wadden Sea (improvement of ecological knowle dge).

(2) To present scientifically based strategies for the improvement of the present environmental situation in the Wadden Sea (support of 'first-aid'measures).

(3) To elaborate tools for future long-term survey and assessment of the environmental situation in the Wadden Sea (support of preventive and protective measures).

\section{THE IMPORTANCE OF SPATIO-TEMPORAL SCALES IN ECOLOGICAL RESEARCH}

Depending on the observer's position, important questions in ecology (such as equilibrium and stability in ecosystems, the role of species in ecosystem processes, etc.) are assessed in different ways. In this context, the choice of scales in space and time for observation is decisive. 
Objects and phenomena within the living world can usually be related to different levels of organization. In a series from the biomolecule to the cell, the organism, the population, the ecosystem, and finally to the entire biosphere, structural complexity increases among biological systems (Fig. 1). This is reflected by a growing number of constituting elements as well as by the increased diversity of external parameters influencing those systems. Furthermore, in the simplest case, each complexity level is composed of the subsystems on the next lower level and is controlled by the level above it (O'Neill et al., 1986).

Hierarchy in structural complexity corresponds to a series of increasing functional

Complexity of system structure [spatial dimension)

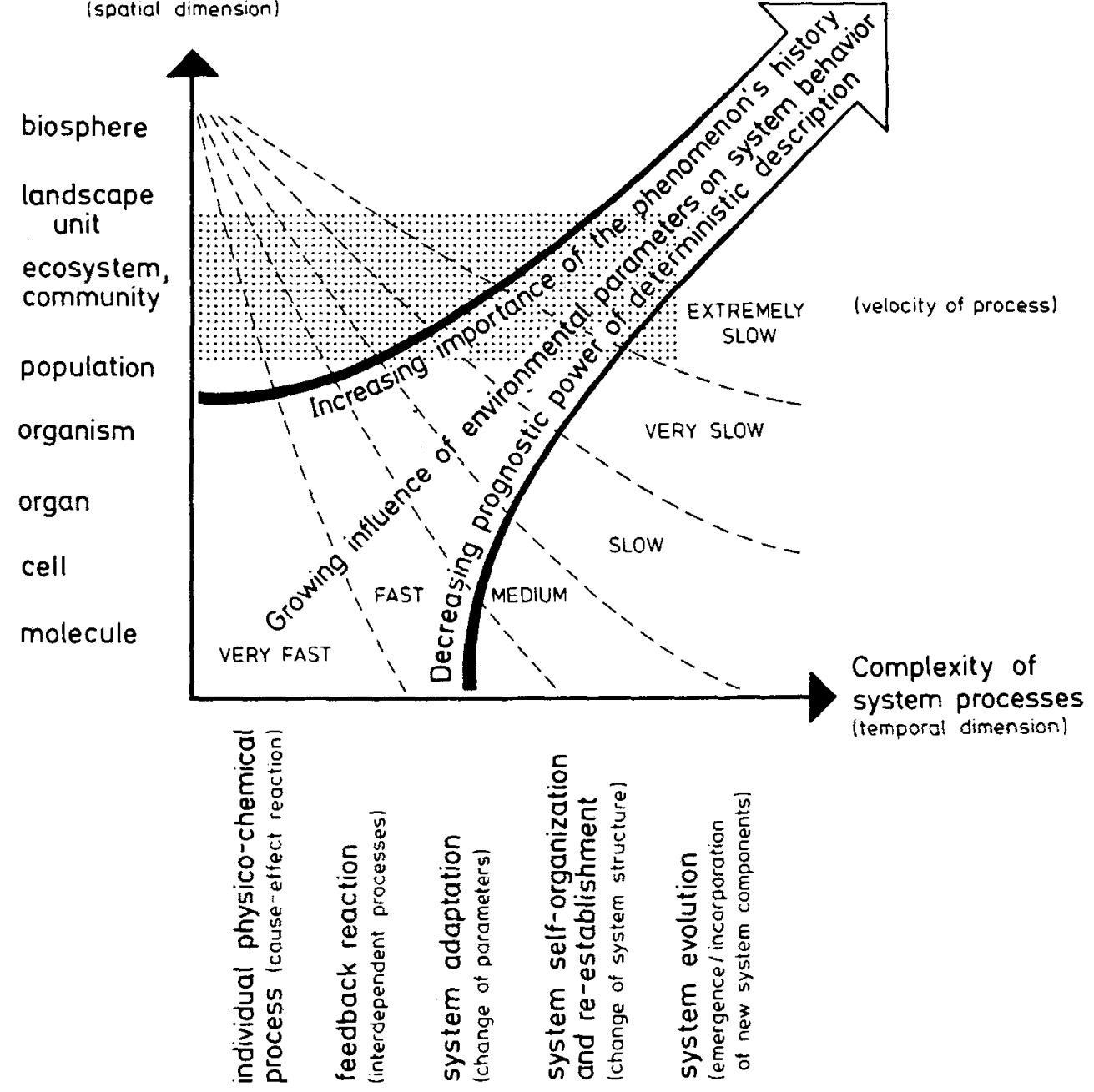

Fig. 1. Hierarchical levels in biological systems relating to structure and function 
complexity in biological systems. The time intervals involved and the number of participating processes increase greatly within such a 'functional hierarchy' from the level of the simple cause-effect reaction to the level of evolutionary processes (Fig. 1).

Byr selecting a certain spatiotemporal 'observational window' within these hierarchies, not only the structural and functional complexities of the objects of study will be determined but also the velocities or, respectively, the rates of the corresponding processes (O'Neill et al., 1986). This is indicated in a schematic manner in Figure 1 by graduations from 'very fast' to 'extremely slow'.

It has to be mentioned here that the above described hierarchical patterns in biological systems are schematic ones that reveal fundamental patterns, but they of course require adjustments if used in practical science.

Nevertheless, it is clear that a complete understanding of the living world requires scientific approaches at all levels of structural and functional hierarchy. Unfortunately, limitations in available time and research funding and also broader scientific interest continually forces scientists to select restricted spatiotemporal windows for their research effort. This will inevitably lead to a biased view of nature, particularly in the case of ecosystem analysis.

Ecosystem research in the Wadden Sea of Schleswig-Holstein will concentrate on the level of communities and ecosystems (as indicated by hatching in Fig. 1). Thus, research will mainly cover such aspects as the distribution patterns of communities, ecosystem types, and abiotic environmental conditions within the Wadden Sea, species diversity in the different communities, foodweb patterns, production, consumption, and mineralization of organic matter in various ecosystems, transport of matter across outer and inner boundaries resp. interfaces of ecosystems as well as homeostatic properties at the ecosystem level. With regard to ecosystem functions, research will cover the individual process level (see Fig. 1) as well as more complex processes such as re-organization and establishment of ecosystems (e.g. investigations on ecosystem succession by initiating long-term studies).

\section{APPROACHES TO ECOSYSTEM ANALYSIS}

Biological science above the complexity level of the organism (including population ecology, ecosystem ecology, landscape ecology) faces three obstacles which, on the one hand, have hindered the establishment of a central core of theories and concepts found in other biological sciences (Fenchel, 1987) and, on the other hand, have led to the existence of competing scientific approaches and methods among ecological disciplines.

(1) Ecosystems and landscape units represent systems which are built up of a rather large number of heterogenous system elements and can be viewed, as does O'Neill et al. (1986), as 'medium-number systems'. These systems do not usually yield to mathematical analysis with each component described by a separate equation, nor can they be sufficiently covered by a statistical approach, which requires a large number of identical system elements. 'There are too many components to describe each by a single equation; there are not enough to simply average properties' (O'Neill et al., 1986). In addition, the multitude of asymmetric interactions between the system elements hinders the isolation of subsystems and thus the intended investigation of them separately.

(2) Ecosystems and landscape units represent biological systems at the upper end of the structural hierarchy and therefore include other systems of different (but lower) 
complexity (from the biomolecule up to populations) and size. This is also valid for the processes involved. Thus, a scientific understanding of ecosystems and landscape units has to consider much wider spatiotemporal scales than, for example, disciplines like molecular biology or physiology.

(3) Properties of ecosystems and landscape units not only express general biological or ecological principles and laws but also, to a considerable extent, express the function of singular historical or evolutionary events in the system's and its components' past. Individual and non-reproducible constraints during the system's establishment resp. evolution, lead often to singular or unique properties among the objects of ecosystem research. Therefore, it also has to be recognized that - in contrast to biological research below the level of the organism - scientific findings at the ecosystem level are usually of limited general validity. The fundamental goal of natural science is to describe nature as simply as possible with out excluding important information (Vollmer, 1988). This can mainly be achieved in disciplines like physics, chemistry or molecular biology through the recognition of general biological principles and laws. None of the above mentioned scientific disciplines however deal with objects or phenomena that are characterized by the properties in (1) to (3).

In contrast to this, complex systems such as ecosystems and landscape units (and also astronomical systems) are determined by a 'dominance of boundary conditions' which lead to the uniqueness of many of their objects. Scientific progress in ecosystem analysis cannot be achieved by the search for general principles concerning structure and function alone, because the neglect of boundary conditions which influence the system would hinder the object's description as well as its explanation. Therefore, the recognition of the characteristic and often unique (singular) properties (which is mainly the purpose of natural history) represents an important element of ecosystem and landscape ecology. This is especially valid in the case of applied ecosystem research.

Ecosystem research has been conducted using different scientific approaches and research strategies. Fundamental differences exist between the population-community approach and the process-functional approach to ecosystem analysis, the former mainly concentrating on biological phenomena in the context of populations and their interaction, the latter predominantly dealing with biotic as well as abiotic phenomena relating to ecosystem level processes (see O'Neill et al., 1986).

Both approaches can deliver important contributions to the understanding of ecosystems and landscape units (Table 1), but also exhibit specific limitations. According to the structural hierarchy in biological systems presented in the chapter on "The importance of spatio-temporal scales in ecological research" one can relate both approaches to different organisation levels, the former concentrating rather on populations, the latter emphasizing ecosystem level phenomena. Both ecological schools try to explain their specific observations in terms of the properties of the composing parts: the population-community approach does this by examining the organisms, the process-functional approach by investigating the ecosystem's functional compartments (e.g. pelagic primary producers) (see Table 2). However, the examination of the respective higher complexity levels is required in both approaches in order to reveal the significance of the observation in nature as well as the role of control mechanisms.

Until now, only a few attempts have been undertaken to reach a necessary synthesis of both approaches. Among supporters of both schools an intuitive rejection of different 
Table 1. Hierarchies in biological systems and corresponding scientific approaches

\begin{tabular}{|c|c|c|}
\hline Level of organization & Involved scientific disciplines & Possible gain of knowledge \\
\hline $\begin{array}{l}\text { Landscape unit, ecosystem } \\
\text { complex }\end{array}$ & $\begin{array}{l}\text { Biogeochemistry, biogeogra- } \\
\text { phy, meteorology }\end{array}$ & $\begin{array}{l}\text { Regional exchange of matter } \\
\text { (input-output-balances, } \\
\text { source-sink-strength, meso- } \\
\text { scale transport processes), eco- } \\
\text { system distribution }\end{array}$ \\
\hline Ecosystem, community & $\begin{array}{l}\text { Process-functional approach to } \\
\text { ecosystem analysis, biogeo- } \\
\text { chemistry }\end{array}$ & $\begin{array}{l}\text { Matter and energy turnover } \\
\text { within ecosystems, foodweb } \\
\text { patterns, role of species in eco- } \\
\text { system processes, mainte- } \\
\text { nance of diversity and orga- } \\
\text { nism abundance }\end{array}$ \\
\hline $\begin{array}{l}\text { Functional ecosystem } \\
\text { component }\end{array}$ & $\begin{array}{l}\text { Process-functional approach to } \\
\text { ecosystem analysis }\end{array}$ & $\begin{array}{l}\text { Behaviour and regulation of } \\
\text { fundamental ecosystem pro- } \\
\text { cesses (production, consump- } \\
\text { tion, mineralization etc.) }\end{array}$ \\
\hline Population of organisms & $\begin{array}{l}\text { Population-community ap- } \\
\text { proach to ecosystem analysis, } \\
\text { population genetics }\end{array}$ & $\begin{array}{l}\text { Population dynamics and spe- } \\
\text { cies interactions (natality, } \\
\text { growth, mortality, predation, } \\
\text { competition, migration etc.) }\end{array}$ \\
\hline Organism & $\begin{array}{l}\text { Ecophysiology, behavioural } \\
\text { biology, natural history }\end{array}$ & $\begin{array}{l}\text { Performance and behaviour of } \\
\text { individual organisms in their } \\
\text { environment }\end{array}$ \\
\hline Organ, cell & $\begin{array}{l}\text { Physiology, biochemistry, bio- } \\
\text { physics, anatomy }\end{array}$ & $\begin{array}{l}\text { Physical and biochemical me- } \\
\text { chanisms within an organism }\end{array}$ \\
\hline Biomolecule & $\begin{array}{l}\text { Molecular biology, genetics, } \\
\text { biochemistry }\end{array}$ & $\begin{array}{l}\text { Physical and chemical mecha- } \\
\text { nisms at the molecular level }\end{array}$ \\
\hline
\end{tabular}

perspectives on ecosystems is dominating (e.g. Fenchel, 1987), which does not help to improve the tools of ecosystem analysis.

Besides different scientific approaches (as mentioned before), research at the ecosystem level requires various ecological research strategies: des cription of the object's or phenomenon's properties should always be the first step towards the understanding of observations. Within the context of the $\mathrm{causal-functional} \mathrm{research} \mathrm{strategy,} \mathrm{an}$ attempt is made to explain the object's structure and function in terms of the properties of subsystems at lower complexity levels. Clearly, a strong scientific reductionism faces certain limitations in biology (e.g. Vollmer, 1988) as well as in the field of ecosystem analysis (Levins \& Lewontin, 1980). Finally, the third important research strategy in ecological science intends to explain observations in terms of their histarical or, respectively, their evolutionary background.

Ecological research can be conducted either in the field by observing, comparing or manipulating the object of study, or in a labor a tory resp. microcos m. In the case of ecosystem and landscape studies the former approach seems to be more important. 
Table 2. The two main approaches to ecosystem analysis in relation to the levels of organization in biological systems (following O'Neill et al., 1986)

\begin{tabular}{|c|c|c|}
\hline $\begin{array}{l}\text { Levels of } \\
\text { organization }\end{array}$ & $\begin{array}{l}\text { Population-community approach } \\
\text { to ecosystem analysis }\end{array}$ & $\begin{array}{c}\text { Process-functional approach to } \\
\text { ecosystem analysis }\end{array}$ \\
\hline $\begin{array}{l}\text { Landscape unit, eco- } \\
\text { system complex }\end{array}$ & & Biological significance \\
\hline Ecosystem, & Biological significance & Observations \\
\hline $\begin{array}{l}\text { Functional ecosy- } \\
\text { stem component }\end{array}$ & & Causal explanation \\
\hline Population & $\overline{\text { Observations }}$ & \\
\hline Organism & Causal explanation & \\
\hline
\end{tabular}

Furthermore mathe matical models can be used to gain insight into ecological systems. This has been demonstrated especially in the case of models describing parts or compartments of ecosystems where they can be valuable heuristic devices. Simulating complete ecosystems or landscape units seems to be less successful, particularly if quantitative predictions for management purposes are expected (Mann, 1982). Continually changing boundary conditions, the existence of non-linear processes, and the limited knowledge on adaptation (or other complex) processes within ecosystem compartments hinders in most cases the sound extrapolation of the system's behaviour into the future by means of a mathematical model. This seems to be demonstrated by the results of several ecosystem modelling efforts especially in North American coastal ecosystems (e.g. Boynton et al., 1977; Gordon et al., 1986; Hopkinson \& Day, 1977; Johnson, 1980; Kremer \& Nixon, 1978; Pomeroy \& Wiegert, 1981).

Therefore, modelling efforts within the ecosystem research project in the Wadden Sea of Schleswig-Holstein will concentrate on well understood ecosystem compartments (e.g. the construction of high resolution tidal transport models). Instead of building own ecosystem models, it is intended to examine the applicability of the recently established ecosystem model of the Western Dutch Wadden Sea (Baretta \& Ruardij, 1988) to the results of the present study. In this way, it is hoped to combine a matured ecosystem model with an extensive set of empirical data which will be collected within the framework of the project. Thus, the validation (or falsification) of existing ecosystem models by means of a comprehensive basis of field data will be emphasized. This has frequently been neglected during the past. 


\section{APPLIED ECOSYSTEM RESEARCH: INCLUSION OF GEOGRAPHICAL APPROACHES AND RESEARCH ON REGIONAL SOCIO-ECONOMICAL SYSTEMS}

Landscape units such as the Wadden Sea of Schleswig-Holstein (covering about $2850 \mathrm{~km}^{2}$ ) confront scientists with a considerable spatial and temporal variability of properties. By means of a computer-based geographical information system it is hoped to present important ecological and socio-economical variables of the region of study in a manner that enables further interpretation and computation of the data. The concept of a geographical information system for the Wadden Sea mainly follows experience taken from its application in terrestrial landscape ecology (e.g. Grossmann et al., 1983). An attempt has been made to adopt this geographically orientated approach within the framework of this project for the purpose of environmental management and protection in the Wadden Sea of Schleswig-Holstein. A list of relevant abiotical, biotical, and socioeconomical variables has been compiled in order that they may be included in the system (Leuschner, 1988). It is intended to use data from existing aerial surveys, maps, statistics, and other written information as well as to conduct additional field surveys.

Traditionally, ecosystem research has concentrated on natural (or semi-natural) systems in which man is viewed as an external factor. However, in our times most ecosystems of the industrialized countries are extensively shaped and influenced by human activity. Therefore, the understanding of the structure and function of ecosystems requires insight into the socio-economical systems which are interconnected with their natural counterparts (Haber, 1986). Consequently, ecosystem research in the Wadden Sea of Schleswig-Holstein will include investigations on several regional socio-economical systems (Fig. 2). In this context, ecosystem research covers both the analysis of natural as well as man-made systems and their interaction.

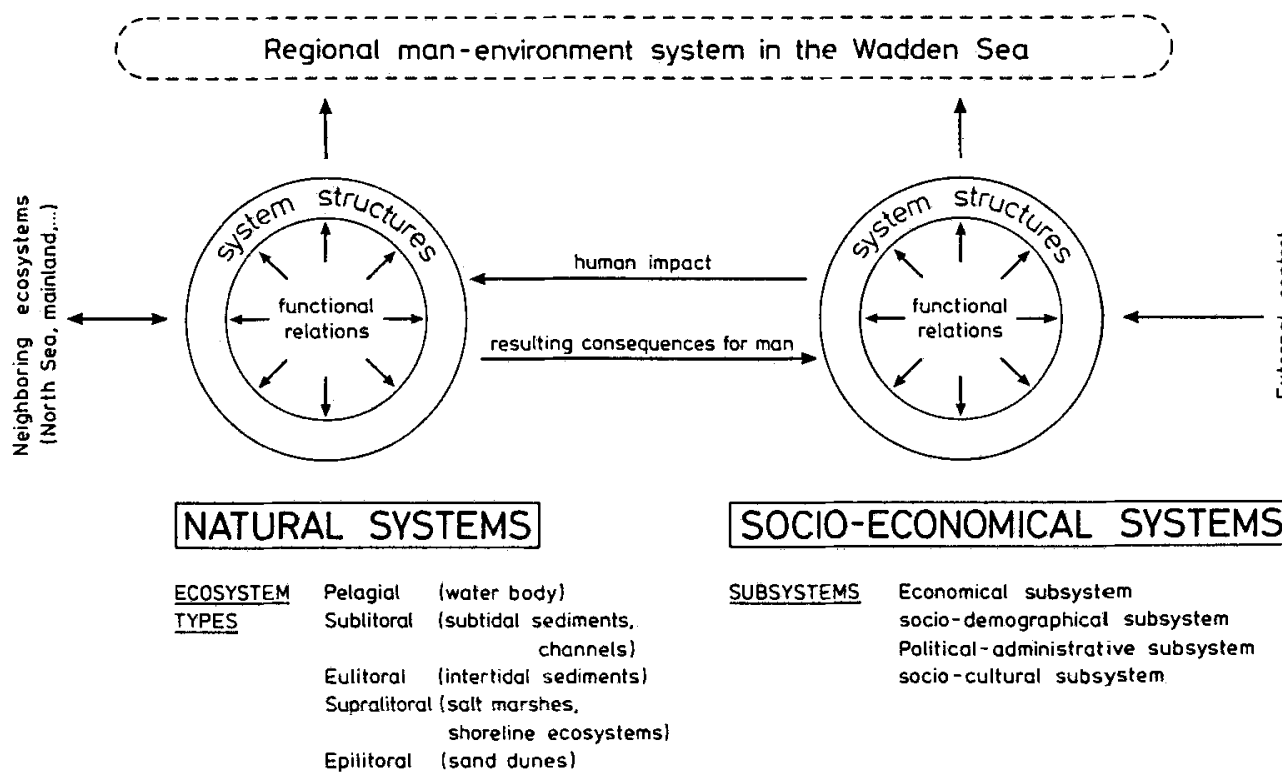

Fig. 2. Objects of an applied ecosystem research in the Wadden Sea 


\section{CONTENTS OF THE ECOSYSTEM RESEARCH PROJECT IN THE WADDEN SEA OF SCHLESWIG-HOLSTEIN: AN OVERVIEW}

The project will be divided into three sections:

S e ct i o n A will mainly use descriptive and historical research strategies in order to investigate structural aspects of the natural and socio-economical systems with regard to their spatial and temporal variability in the region. An important step will be the establishment of the geographical information system WATiS which is currently to be installed at the GKSS-Forschungszentrum at Geesthacht (Krasemann, unpubl.). Based on additional specialised studies on the impact of human activities on local ecosystems (e.g. mussel and shrimp fisheries, tourism, and sheep grazing of salt marshes), the results of the project's research activities are to be presented in a manner that allows the direct use by the state and federal agencies for environmental management and ecosystem protection in the region of the Schleswig-Holstein Wadden Sea.

Section B will predominantly deal with functional properties of the marine and semiterrestrial ecosystems in the Wadden Sea. Research will be focused on physical and biological transport processes at the outer and inner boundaries and interfaces of the Wadden Sea ecosystems and their compartments. Due to favourable hydrographical conditions and the location of suitable research facilities, the Wadden Sea region between Sylt and Romo on the German-Danish border has been selected for these intensive process studies in the marine environment. Unlike the Ems-Dollart-estuary which was the object of the Dutch BOEDE ecosystem project in the Wadden Sea, the SyltRomo research site represents the Wadden Sea bight ecosystem type.

Studies on matter transport and turn-over within salt marshes will be conducted at the neighbouring grazed and ungrazed marshes near Dagebüll in Northern Frisia.

Table 3. Overview of the contents of the planned ecosystem research project in the Wadden Sea of Schleswig-Holstein

Section A

A 0 Documentation and project information

A 1 Establishment of the geographical information system WATiS

A 2 Field surveys for the information system

A 3 Analysis of the socio-economical systems of the region

A 4 Analysis of the ecosystems' recent and historical development

A 5 Sensitivity of qualitative biological indicators

A 6 Case studies on the impact of human activity in the Wadden Sea

A 7 Pollutants in the Wadden Sea of Schleswig-Holstein

Section $\mathbf{B}$

B 0 Boundary conditions in the research site Sylt-Romo-Wadden Sea

B 1 Organism mediated turn-over processes

B 2 Measurement and modelling of transport processes

B 3 Exchange processes at ecosystem boundaries and interfaces

B 4 Balance of matter turn-over at the Sylt-Romo-Wadden Sea

B 5 Balance of matter turn-over in salt marshes of Northern Frisia

Section $C$

Project administration

Public relations section 
The projects of section A correspond with the two 'applied' goals of the project: (1) support of 'first-aid' measures (see p. 566; project A 6 in Table 3); (2) support of preventive and protective measures (projects A 1, A 2, A 5, A 6 in Table 3).

In contrast, section B mostly represents projects of basic natural science.

Section C contains the project's administrative organs.

A more detailed description of the proposed research program is enclosed in Leuschner (1988). Table 3 lists the planned sub-projects.

Acknowledgements. We wish to thank Prof, M. Runge and Prof. B. Ulrich (both Göttingen) for their comments on the manuscript, Prof. K. Reise (List, Syit) for instructive walks and talks in the mud, and David Fleet for improving our English.

\section{LITERATURE CITED}

ARSU GmbH, 1988. Programmkonzeption zur Ökosystemforschung im niedersächsischen Wattenmeer. - Forsch. Ber. Umweltbundesamt Berlin 10902020/02, 1-183.

Baretta, J. W. \& Ruardij, P. (ed.) 1988. Tidal flat estuaries. Springer, Berlin 353 pp.

Boynton, W., Hawkins, D. E. \& Gray, C., 1977. A modelling approach to regional planning in Franklin county and Apalachicola Bay, Florida. In: Ecosystem modelling in theory and practice. Ed. by C.A.S. Hall \& J.W. Day. Wiley, New York, 477-506.

Fenchel, T., Ecology - potentials and limitations. Ecology Institute, Oldendorf, $186 \mathrm{pp}$.

Gordon, D. C., Keizer, P. D., Daborn, G. R., Schwinghamer, P. \& Silvert, W. L., 1986. Adventures in holistic ecosystem modelling: The Cumberland Basin ecosystem model. - Neth. J. Sea Res. 20, 325-335.

Grossmann, W.-D., Haber, W., Kerner, H., Kunz, A., Richter, U., Schaller, J., Sittard, M. \& Spandau, L., 1983. Ökosystemforschung Berchtesgaden. Durchführung des MAB-Projektes 6 "Der Einfluß3 des Menschen auf Hochgebirgsökosysteme". Ziele, Fragestellungen und Methoden. - MABMitt. Bonn 16, 1-136.

Haber, W., 1986. Umsetzung ökologischer Forschungsergebnisse in politisches Handeln. - MABMitt. Bonn 22, 3-16.

Hopkinson, C. S. \& Day, J. W. 1977. A model of the Barataria Bay salt marsh ecosystem. In: Ecosystem modelling in theory and practice. Ed. by C. A. S. Hall \& J. W. Day. Wiley, New York, 235-266.

Johnson, R. W., 1980. Simulation modelling of estuarine ecosystems. In: Estuarine and wetland processes. Ed. by P. Hamilton \& K. B. MacDonald. Plenum Press, New York, 541-560.

Kremer, J. N. \& Nixon, S. W., 1978. A coastal marine ecosystem. Springer, Berlin, 217 pp.

Leuschner, Ch., 1988. Ökosystemforschung Wattenmeer - Hauptphase Teil 1: Erarbeitung der Konzeption sowie Organisation des Gesamtvorhabens (Forschungsverbund). - Forsch. Ber. Umweltbundesamt Berlin 10902020/01, 1-155.

Levins, R. \& Lewontin, R., 1980. Dialectics and reductionism in ecology. - Synthese 43, 47-78.

Mann, K. H., 1982. Ecology of coastal waters. Blackwell, Oxford, 322 pp.

O'Neill, R. V., DeAngelis, D. L., Waide, J. B. \& Allen, T. F. H., 1986. A hierarchical concept of ecosystems. Princeton Univ. Press, Princeton, 253 pp.

Pomeroy, L. R. \& Wiegert, R. G. (eds.), 1981. The ecology of a salt marsh. Springer, New York, 271 pp.

Vollmer, G., 1988. Ordnung ins Chaos? Zur Weltbildfunktion wissenschaftlicher Erkenntnis. Naturwiss. Rdsch., Stuttg. 345-350. 